\title{
The Effect of Coconut Water (Cocos nucifera L.) and Atonik to The Growth of Tomato Plant (Lycopersicum esculentum Mill.)
}

\author{
Intan Poespita Windiyani, Tundjung Tripeni Handayani, Zulkifli, Bambang Irawan \\ Jurusan Biologi, Fakultas Matematika dan IImu Pengetahuan Alam Universitas Lampung \\ Jalan. Prof. Soemantri Brojonegoro, Bandar Lampung, 35145 \\ Email: intanpoespitawindiyanii@gmail.com
}

\begin{abstract}
The purpose of this study was to find how the effects of coconut water plus atonic on tomato plant growth. The study was conducted from October to November 2019 at the Laboratory of Botany, Department of Biology FMIPA University of Lampung. The study was conducted in a $2 \times 3$ factorial experiment with a completely randomized design. Factor $\mathrm{A}$ is young coconut water with 3 levels of concentration i.e. $0 \% \mathrm{v} / \mathrm{v}, 25 \% \mathrm{v} / \mathrm{v}$, and $50 \% \mathrm{v} / \mathrm{v}$. Factor B is atonic with 2 concentration levels, namely $0 \% \mathrm{v} / \mathrm{v}$ and $10 \% \mathrm{v} / \mathrm{v}$. As variables are high, fresh weight, dry weight, relative water content, and chlorophyll content of plants. Levene Test, Variance Analysis is carried out at a $5 \%$ significance level. Main effects and simple effects were analyzed by the Tukey test at $5 \%$ significance level. The results showed that the interaction between coconut water and atonic had a negative effect on the growth of tomato plants. The results of the study concluded that coconut water combine with atonic can not improve tomato plant growth.
\end{abstract}

Keywords: tomato (Lycopersicum esculentum Mill.), coconut water, atonic.

\section{PENDAHULUAN}

Tanaman tomat dikenal dengan nama latin Lycopersicum esculentum Mill., berasal dari keluarga solanaceae, dan merupakan tanaman asli Amerika Tengah dan Selatan. Tomat adalah tanaman yang memiliki siklus hidup yang singkat dan hanya bereproduksi satu kali dalam masa tanam. Buah tomat kaya vitamin dan mineral. Daerah yang ideal untuk pertumbuhan tomat adalah daerah yang tanahnya gembur dengan tingkat $\mathrm{pH}$ sekitar 5,5 sampai 7 (Rinaldi, 2019).

Tomat di Indonesia merupakan salah satu komoditas hortikultura yang memiliki nilai ekonomi yang tinggi namun produktivitasnya masih tergolong rendah. Faktor dominan penyebab rendahnya produktivitas tanaman adalah kualitas biji dan bibit yang kurang baik serta yang paling menonjol adalah kurangnya ketersediaan unsur hara yang cukup pada media tanam yang digunakan.

Peningkatan produktivitas tanaman dapat dilakukan dengan pemupukan yaitu menggunakan kombinasi antara pupuk alami air kelapa dan atonik sebagai biostimulan, juga dengan menggunakan biji dan bibit yang berkualitas. Bibit yang berkualitas akan diperoleh dari biji yang berkualitas, yaitu biji yang telah tersertifikasi yang dapat diperoleh di toko pertanian. Kemudian, dipilih biji yang bersih, tidak cacat dan bernas sehingga diharapkan akan diperoleh kecambah yang baik akan menghasilkan bibit yang berkualitas.

Salah satu senyawa alami yang dapat meningkatkan pertumbuhan tanaman adalah senyawa yang terkandung dalam air kelapa (Cocos nucifera L.). Air kelapa yang sering dibuang oleh para pedagang di pasar tidak ada salahnya bila dimanfaatkan untuk menyiram tanaman.Hasil penelitian menunjukkan air kelapa mengandung gula antara 1,7 sampai $2,6 \%$, protein 0,07 hingga $0,55 \%$ mineral, potassium (kalium) hingga 17\%, dan mengandung vitamin. Mineral lainnya antara lain natrium $(\mathrm{Na})$, 
kalsium (Ca), magnesium (Mg), ferum (Fe), cuprum $(\mathrm{Cu})$, fosfor $(\mathrm{P})$ dan sulfur $(\mathrm{S})$. Pada air kelapa terdapat hormon alami yaitu hormon auksin dan sitokinin sebagai pendukung pembelahan sel embrio kelapa (Metusala, 2012 dalam Pranata., 2018).

Hasil penelitian Purba (2017), dalam hal ini pemberian air kelapa konsentrasi 250 $\mathrm{ml} /$ plot berpengaruh nyata terhadap pertumbuhan dan produksi tanaman sawi pakcoy karena air kelapa banyak mengandung zat pengatur tumbuh yaitu auksin, sitokinin dan giberelin yang dapat meningkatkan pertumbuhan dan perkembangan tanaman. Menurut Nurman dkk. (2017), pemberian ZPT air kelapa dengan konsentrasi $50 \%$ dan $75 \%$ nyata lebih banyak menghasilkan berat umbi kering bawang merah per $\mathrm{m}^{2}$ dibanding dengan tanpa pemberian air kelapa, tetapi berbeda tidak nyata dengan pemberian air kelapa 25\%.

Biostimulan yang dapat digunakan sebagai zat pengatur tumbuh salah satunya adalah atonik. Zat pengatur tumbuh dapat mendorong pertumbuhan akar sehingga penyerapan hara menjadi lebih efektif. ZPT Atonik di dalam tanaman dapat berfungsi untuk memacu pertumbuhan tanaman, memperbaiki mutu dan meningkatkan hasil tanaman (Lestari, 2011). Atonik adalah biostimulan yang disintesis dari bahan aktif natrium senyawa fenol dan berfungsi sebagai karier metabolit dalam proses metabolisme. Ion $\mathrm{Na}^{+}$mampu menggantikan sebagian fungsi ion $\mathrm{K}^{+}$. Bahan utama komponen aktif terdiri dari natrium 5-nitroguaicol $\quad\left(\mathrm{C}_{7} \mathrm{H}_{6} \mathrm{NO}_{4} \mathrm{Na}\right)$, natrium ortonitrofenol $\left(\mathrm{C}_{6} \mathrm{H}_{4} \mathrm{NO}_{3} \mathrm{Na}\right)$, natrium para-nitrofenol $\left(\mathrm{C}_{6} \mathrm{H}_{4} \mathrm{NO}_{3} \mathrm{Na}\right.$, $)$ dan natrium 2,4- dinitrofenol $\left(\mathrm{C}_{6} \mathrm{H}_{3} \mathrm{~N}_{2} \mathrm{O}_{5} \mathrm{Na}\right.$ ) (Afandhie dan Yuwono, 2007). Peran atonik pada tanaman berfungsi untuk merangsang pertumbuhan akar tanaman yang lebih banyak, mengaktifkan penyerapan unsur hara, meningkatkan keluarnya kuncup dan buah serta memperbaiki kualitas panen (Kusumo, 1984). Hasil penelitian Rachmawati dkk. (2017) menunjukkan bahwa pemberian atonik $40 \%$ dan air kelapa $60 \%$ dapat meningkatkan perkecambahan lebih tinggi dan jumlah daun pada bud chips tebu yang secara nyata lebih tinggi dibandingkan dengan perlakuan lainnya.

\section{BAHAN DAN METODE}

Penelitian ini dilakukan di Laboratorium Botani Fakultas Matematika dan IImu Pengetahuan Alam Universitas Lampung dari Oktober - November 2019.

Penelitian ini merupakan penelitian faktorial 2 x 3 menggunakan Rancangan Acak Lengkap (RAL). Faktor A adalah air kelapa muda dengan 3 taraf konsentrasi yaitu $0 \%$ $\mathrm{v} / \mathrm{v}, 25 \% \mathrm{v} / \mathrm{v}$ dan $50 \% \mathrm{v} / \mathrm{v}$ dan faktor B adalah larutan atonik dengan 2 taraf konsentrasi yaitu $0 \% \mathrm{v} / \mathrm{v}$ dan $10 \% \mathrm{v} / \mathrm{v}$, sehingga diperoleh 6 kombinasi perlakuan. Setiap kombinasi perlakuan diulang 5 kali, sehingga diperoleh 30 satuan percobaan. Sebagai variabel adalah tinggi, berat segar, berat kering, kadar air relatif, kandungan klorofil a, b, dan total tanaman. Pengambilan data untuk tinggi tanaman dilakukan pada saat tanaman berumur 4 minggu setelah perlakuan. Uji Levene dilanjutkan dengan Analisis Ragam pada taraf nyata 5\%. Apabila hasil anara interaksi antara kedua faktor (faktor A dan faktor B) dinyatakan signifikan (nyata) maka dilakukan uji lanjut penentuan simple effect dengan uji Tukey pada nyata 5\%. Jika interaksi kedua faktor tidak signifikan (nyata) maka ditentukan main effect dengan uji Tukey pada taraf nyata $5 \%$.

\section{HASIL}

\section{Tinggi Tanaman}

Analisis ragam menunjukkan bahwa air kelapa, atonik, serta interaksi antara air kelapa dan atonik berpengaruh nyata terhadap tinggi tanaman tomat $(p<0.05)$. Analisis simple effect atonik berdasarkan uji Tukey menunjukkan bahwa atonik dengan air kelapa $0 \%$ dan $25 \% \quad \mathrm{v} / \mathrm{v}$ tidak berpengaruh nyata terhadap tinggi tanaman. Interaksi atonik $10 \%$ dengan air kelapa $50 \% \mathrm{v} / \mathrm{v}$ memberikan efek negatif yaitu menyebabkan tinggi tanaman lebih 
rendah dibanding tinggi tanaman perlakuan kombinasi atonik $0 \%$ dengan air kelapa $50 \%$.

Rata-rata tinggi tanaman disajikan pada Gambar 1.

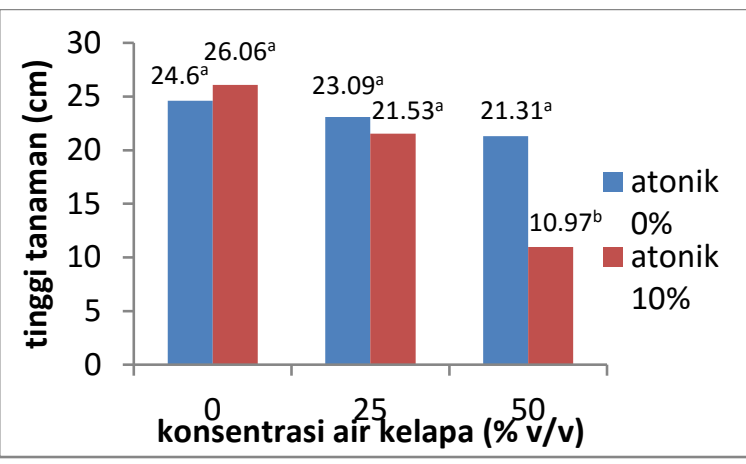

Gambar 1. Grafik interaksi antara air kelapa dan atonik terhadap tinggi tanaman tomat 4 minggu setelah perlakuan

\section{Berat Segar Tanaman}

Rata-rata berat segar disajikan pada Gambar 2.

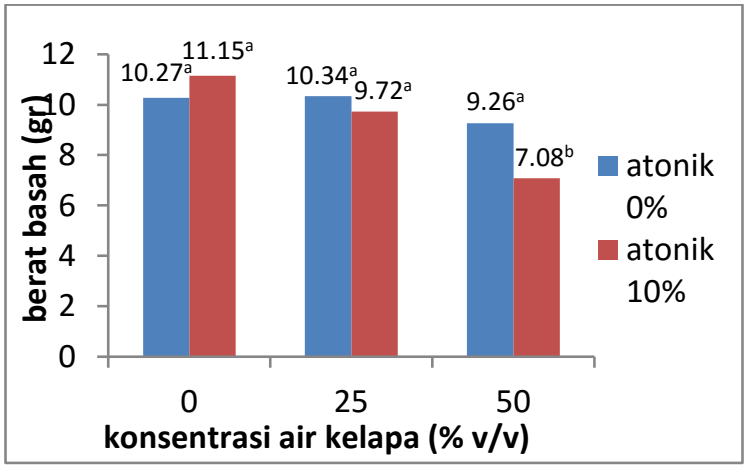

Gambar 2. Grafik interaksi antara air kelapa dan atonik terhadap berat segar tanaman tomat

Analisis ragam menunjukkan bahwa air kelapa dan interaksinya dengan atonik berpengaruh nyata $(p<0.05)$ sedangkan atonik tidak berpengaruh nyata $(p>0.05)$. Analisis simple effect menunjukkan bahwa atonik dengan air kelapa $0 \%$ dan $25 \% \mathrm{v} / \mathrm{v}$ tidak berpengaruh nyata terhadap berat segar tanaman. Interaksi atonik 10\% dengan air kelapa $50 \% \mathrm{v} / \mathrm{v}$ memberikan efek negatif yaitu menyebabkan berat segar yang lebih kecil dibanding dengan berat segar kombinasi atonik $0 \%$ dengan air kelapa $50 \%$.

\section{Berat Kering Tanaman}

Rata-rata berat kering disajikan pada Gambar 3.

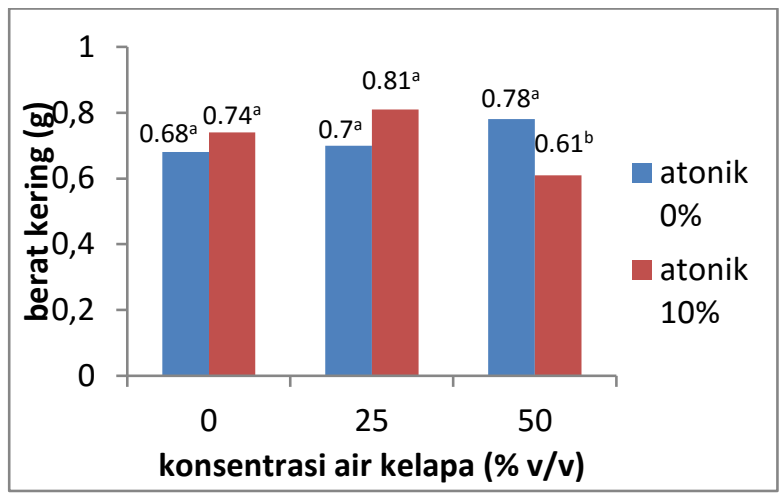

Gambar 3. Grafik interaksi antara air kelapa dan atonik terhadap berat kering tanaman tomat

Analisis ragam menunjukkan bahwa perlakuan air kelapa dan atonik tidak berpengaruh nyata terhadap berat kering ( $>0.05)$, tetapi interaksi antara air kelapa dan atonik memberikan pengaruh yang nyata $(p<0.05)$. Analisis simple effect menunjukkan bahwa interaksi atonik $0 \%$ dan air kelapa $25 \% \mathrm{v} / \mathrm{v}$ tidak berpengaruh nyata terhadap berat kering tanaman. Interaksi atonik 10\% dengan air kelapa 50\% $\mathrm{v} / \mathrm{v}$ memberikan efek negatif yaitu menyebabkan berat kering yang lebih kecil dibanding dengan berat kering kombinasi atonik $0 \%$ dengan air kelapa $50 \%$.

\section{Kadar Air Relatif}

Analisis ragam menunjukkan bahwa perlakuan atonik dan interaksinya antara atonik dengan air kelapa tidak berpengaruh nyata, tetapi perlakuan air kelapa berpengaruh nyata terhadap kadar air relatif $(p<0.05)$. Grafik main effect air kelapa terhadap tanaman tomat ditunjukkan pada Gambar 4.

Berdasarkan Gambar 4, rata-rata kadar air relatif hasil perlakuan air kelapa $0 \%$ tidak berbeda nyata dengan hasil perlakuan air kelapa $25 \% \mathrm{v} / \mathrm{v}$, tetapi berbeda nyata dengan hasil perlakuan air kelapa 50\% v/v. 


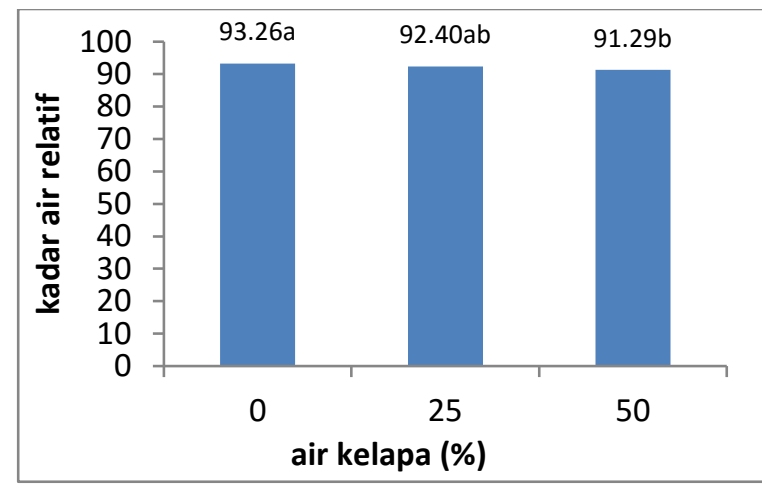

Gambar 4. Grafik main effect air kelapa terhadap kadar air relatif tanaman tomat

\section{Kandungan Klorofil a, b dan Total}

Analisis ragam menunjukkan bahwa perlakuan atonik, air kelapa, dan interaksi atonik dengan air kelapa tidak berpengaruh nyata terhadap kandungan klorofil a, klorofil $b$, dan klorofil total tanaman tomat $(p>0.05)$. Dengan demikian analisis data tidak dilanjutkan ke analisis lanjut menggunakan Uji Tukey.

\section{PEMBAHASAN}

Interaksi atonik dengan air kelapa 0\% dan $25 \%$ tidak memberikan hasil yang berbeda nyata terhadap tinggi tanaman tomat. Perlakuan kombinasi air kelapa 0\% + atonik $10 \%$ memberikan hasil terbaik pada tinggi tanaman. Hal ini diduga karena atonik merupakan biostimulan yang dapat menstimulasi pertumbuhan tinggi tanaman dan pada konsentrasi yang tepat akan mendorong terjadinya pembelahan dan perpanjangan sel serta mengaktifkan penyerapan unsur hara. Hal ini sejalan dengan Lestari (2011), zat pengatur tumbuh atonik dapat mendorong pertumbuhan akar sehingga penyerapan hara menjadi lebih efektif.

Selanjutnya Lestari (2011) menjelaskan bahwa biostimulan atonik dalam cara kerjanya cepat terserap oleh tanaman dan merangsang aliran protoplasmatik serta mempercepat perkecambahan dan pertumbuhan akar, pemberian atonik pada konsentrasi yang tepat dapat merangsang seluruh jaringan tumbuhan secara biokimiawi dan langsung terserap akar, selanjutnya diteruskan ke batang dan daun sehingga bisa mempercepat proses metabolisme pada tanaman, tetapi bila konsentrasinya berlebihan maka dapat bersifat sebagai inhibitor yaitu menghambat proses metabolisme.

Pemberian air kelapa dan atonik konsentrasi tertinggi (air kelapa 50\% + atonik 10\%) menghasilkan tinggi tanaman, berat segar dan berat kering yang lebih rendah dibanding dengan kombinasi perlakuan yang lain. Hal ini diduga karena terlalu tingginya konsentrasi air kelapa maupun atonik yang diberikan. Atonik merupakan zat pengatur tumbuh dan di dalam air kelapa terkandung hormon sitokinin dan auksin, pada kombinasi air kelapa $50 \%$ + atonik 10\% menyebabkan hormon yang terkandung terlalu tinggi, sehingga pada tanaman dapat bersifat sebagai inhibitor yaitu penghambat proses metabolisme. Hal ini sejalan dengan yang dikemukakan oleh Supriyanto dan Prakasa (2011) yang menjelaskan bahwa pada kadar rendah hormon atau zat pengatur tumbuh akan mendorong pertumbuhan, sedangkan pada kadar lebih tinggi akan menghambat pertumbuhan, meracuni dan bahkan mematikan tanaman.

Interaksi air kelapa dan atonik tidak berpengaruh terhadap kadar relatif tanaman tomat. Diduga karena jumlah air yang terkandung dalam tubuh tanaman berbedabeda, bergantung pada jenis tanaman tersebut. Hal tersebut sejalan dengan Kramer (1972) bahwa turgiditas relative berbanding terbalik dengan deficit air, stomata daunnya menutup akibat menurunnya turgor sel daun sehingga jumlah $\mathrm{CO}_{2}$ yang berdifusi ke daun mengalami pengurangan. Kecuali dengan menutupnya sel, laju transpirasi akan menurun sehingga mengurangi suplai unsur hara dari tanah ke tanaman menyebabkan selnya tidak bertambah banyak namun hanya air yang berselisih pada saat penyerapan air.

Pemberian kombinasi air kelapa dan atonik tidak memberikan pengaruh nyata terhadap 
kandungan klorofil a, klorofil b dan klorofil total, diduga unsur hara yang mengandung $\mathrm{N}$ dan $\mathrm{Mg}$ pada semua kombinasi perlakuan terserap pada tanaman dalam jumlah yang sama. Unsur N dan $\mathrm{Mg}$ diperoleh dari media tanam yang digunakan yaitu tanah dengan kompos sehingga tidak berpengaruh nyata terhadap klorofil a, b dan total. Syafi (2008) menyatakan bahwa ketersediaan unsur $\mathrm{N}$ dan $\mathrm{Mg}$ yang berperan penting dalam sintesis klorofil. Disamping itu, diduga ada pengaruh kurangnya penyerapan cahaya oleh tanaman (Ariani dkk, 2015).

\section{KESIMPULAN}

Dari hasil penelitian disimpulkan bahwa kombinasi air kelapa dan atonik tidak dapat memperbaiki pertumbuhan tanaman tomat.

\section{SARAN}

Hasil penelitian ini perlu dikonfirmasi dengan melakukan penelitian yang sama pada tanaman hortikultura yang lain dengan pemberian atonik dan air kelapa konsentrasi di bawah $25 \%$.

\section{DAFTAR PUSTAKA}

Afandhie R., dan Yuwono, N. W. (2007). IImu Kesuburan Tanah. Yogyakarta: Penerbit Kanisius.

Ariani, Efrida, Fiky, Y. W., Asep, W. I., Tati, N., Dan Yuyun, Y. (2015). Pengaruh Berbagai Pengaturan Jarak Tanam dan Konsentrasi Giberelin $\left(\mathrm{GA}_{3}\right)$ Terhadap Pertumbuhan Dan Hasil Tanaman Gandum (Triticum aestivum L.) Kultivar Dewata di Dataran Medium Jatinangor. Program Studi Agroteknologi. Fakultas Pertanian Universitas Padjajaran. Jurnal Agrikultura, II (1), 31-52.

Kusumo, S. (1984). Zat Pengatur Tumbuh Tanaman. Jakarta: CV. Yasaguna.
Kramer. (1972). Plant and Soil Water Relationship. New York: Mc Graw Hill Company Inc. 428p.

Lestari, B. L. (2011). Kajian Zat Pengatur Tumbuh Atonik dalam Berbagai Konsentrasi dan Interval Penyemprotan terhadap Produktivitas Tanaman Bawang Merah (Allium ascolanicum L.). Fakultas Pertanian Universitas Mochamad Soroedji Jember. J. Rekayasa, 4 (1).

Nurman, Z. E., dan Rahma, D. I. (2017). Pemanfaatan ZPT Air Kelapa Dan POC Limbah Cair Tahu Untuk Pertumbuhan Dan Produksi Bawang Merah (Allium ascalonicum L.). Fakultas Pertanian. Universitas Riau. Jom Faperta UR, 4 (2).

Pranata, E. (2018). Skripsi: Pengaruh Jenis Media Tanam Dan Pemberian Air Kelapa Terhadap Pertumbuhan Tanaman Sawi Pakcoy (Brasicca rapa L.). Medan: Fakultas Pertanian Universitas Muhammadiyah Sumatera Utara.

Purba dan Deddy, W. (2017). Respon Pertumbuhan Dan Produksi Tanaman Sawi Pakcoy (Brassica juncea L.) Terhadap Pemberian Pupuk Organik DOFOSF G-21 Dan Air Kelapa Tua. Fakultas Pertanian UNA. Sumatera Utara. Jurnal Agronomi, 21 (1).

Rachmawati, L. N., Mochammad, R., dan Titiek, I. (2017). Komposisi Atonik Dan Air Kelapa Pada Pertumbuhan Bud Chips Tebu (Saccharum officinarum L.). Fakulltas Pertanian Universitas Brawijaya. Malang. Jurnal Produksi Tanaman. 5 (5), 851-859.

Rinaldi, M. (2019). Panduan Lengkap dan Praktis Budidaya Tomat yang Paling Menguntungkan. Jakarta: Garuda Pustaka. 
29 / Windiyani, I. P.,Handayani, T. T., Zulkifli, Irawan, B

Supriyanto dan Prakasa, K.E. (2011). Pengaruh Zat Pengatur Tumbuh Rootone-F Terhadap Pertumbuhan Stek Dua Bunga Mollucana Blume. Jurnal Silvikultur Tropika, 3 (1), 5965.
Syafi, S. (2008). Tesis. Respons Morfologis dan Fisiologis Bibit Berbagai Genotipe Jarak Pagar. (Jatropha curcas L.) terhadap Cekaman Kekeringan. Bogor: IPB. 